\title{
Seven-year Genotype Distribution Among Hepatitis C Patients in a City in the Central Anatolia Region of Turkey
}

\author{
Iç Anadolu Bölgesinde Bir Șehirde Hepatit C Hastalarının Yedi Yıllık Genotip Dağlımları
}

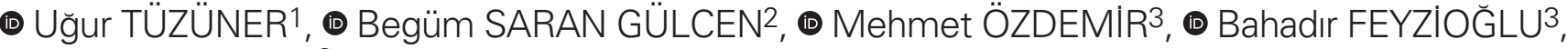 \\ (1) Mahmut BAYKAN3
}

${ }^{1}$ Istanbul Medeniyet University Göztepe Training and Research Hospital, Medical Microbiology Laboratory, Istanbul, Turkey

2Istanbul Kartal Dr. Lütfi Kırdar Training and Research Hospital, Medical Microbiology Laboratory, Istanbul, Turkey

${ }^{3}$ Necmettin Erbakan University Meram Faculty of Medicine, Department of Medical Microbiology, Konya, Turkey

\begin{abstract}
Objectives: Hepatitis C virus (HCV) is an important viral agent of hepatitis, cirrhosis and hepatocellular carcinoma. In our study, we aimed to determine the HCV genotype distribution among patients with HCV who presented to our hospital in a city in the Central Anatolia Region of Turkey.

Materials and Methods: Results of 480 patients who were positive for HCV RNA and whose serum samples were sent to our laboratory from various inpatient and outpatient clinics of the hospital with a pre-diagnosis of hepatitis C between January 2010 and May 2017 were retrospectively screened. In HCV genotype determination, a commercially available kit (Ampliquality HCV-TS, AB Analitica ${ }^{\circledR}$, Italy) based on Reverse Line Blot was used in accordance with the manufacturer's recommendations. Genotype distributions were analyzed by years and by age. The first and only one test results of the same patients were evaluated.

Results: Of the patients whose genotyping was made, 260 $(54.2 \%)$ were female and $220(45.8 \%)$ were male. It was found that $396(82.6 \%)$ of 480 patients were with genotype $1 \mathrm{~b}, 17(3.5 \%)$ genotype $1 \mathrm{a}, 15(3.1 \%)$ - genotype $3 a, 14(2.9 \%)$ - genotype 1, 9 (1.9\%) - genotype 4, $8(1.7 \%)$ - genotype $2,6(1.3 \%)$ - genotype $2 \mathrm{~b}, 5(1.0 \%)$ - genotype 1a/1b, 4 (0.8\%) - genotype 2a/2c, 3 (0.6\%) - genotype $4 a, 1(0.2 \%)$ - genotype $3,1(0.2 \%)$ - genotype $5 a$ and 1 $(0.2 \%)$ patient was with genotype 6 .

Conclusion: In chronic HCV patients admitted to our hospital, genotype $1 \mathrm{~b}$, which had the highest prevalence in our country, was detected with a rate of $82.6 \%$. In addition, the presence of rare genotypes $5 a$ and 6 in our country has been shown.

Keywords: Hepatitis C, reverse hybridization, genotype
\end{abstract}

öz

Amaç: Hepatit C virüsü (HCV), hepatit, siroz ve hepatosellüler karsinomun önemli bir viral etkenidir. Çalışmamızda, Iç Anadolu Bölgesi'nde bir şehirde, hastanemize başvuran HCV ile enfekte hastaların HCV genotip dağılımlarını saptamayı hedefledik.

Gereç ve Yöntemler: Ocak 2010-Mayıs 2017 tarihleri arasında, laboratuvarımıza hastanenin çeşitli klinik ve polikliniklerinden hepatit C ön tanısı ile serum örneği gönderilen ve HCV RNA pozitifliği olan 480 hastanın sonuçları retrospektif olarak tarandı. HCV genotip tayininde, ters hibridizasyon (Reverse Line Blot) temeline dayanan ticari bir kit (Ampliquality HCV-TS; AB Analitica ${ }^{\circledR}$, Italya), üretici firma önerileri doğrultusunda kullanıldı. Genotip dağılımları yıllara ve yaşlara göre incelendi. Aynı hastaların ilk ve tek test sonucu değerlendirmeye alındı.

Bulgular: Genotiplemesi yapılan hastaların 260'ı (\%54,2) kadın, 220 'si $(\% 45,8)$ erkek idi. Toplam 480 hastanın 396'sı $(\% 82,6)$ genotip $1 \mathrm{~b}, 17$ 'si $(\% 3,5)$ genotip $1 \mathrm{a}, 15^{\prime} \mathrm{i}(\% 3,1)$ genotip $3 \mathrm{a}, 14^{\prime} \mathrm{ü}$ $(\% 2,9)$ genotip 1, 9'u $(\% 1,9)$ genotip 4, 8'i $(\% 1,7)$ genotip 2, 6's $(\% 1,3)$ genotip $2 \mathrm{~b}, 5^{\prime} \mathrm{i}(\% 1,0)$ genotip $1 \mathrm{a} / 1 \mathrm{~b}, 4$ 'ü $(\% 0,8)$ genotip $2 a / 2 c$, 3 'ü $(\% 0,6)$ genotip $4 a, 1^{\prime} i(\% 0,2)$ de genotip 3 , genotip $5 a$ ve genotip 6 olarak bulunmuştur.

Sonuç: Hastanemize başvuran kronik HCV hastalarında en sık; ülkemizde de en yüksek prevalansa sahip olan: genotip 1b, \%82,6 oranıyla saptanmıştır. Ayrıca, ülkemizde az görülen genotip $5 a$ ve genotip 6'nın varlığı gösterilmiştir.

Anahtar Kelimeler: Hepatit C, reverse hibridizasyon, genotip

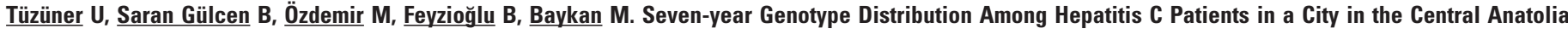
Region of Turkey. Viral Hepat J. 2018;24:12-17. 


\section{Introduction}

Hepatitis $\mathrm{C}$ virus (HCV) infection is an important public health problem due to its chronicity risk up to $80 \%$ and its complications, such as cirrhosis and hepatocellular carcinoma, that may occur in advanced stages. It is estimated that more than 170 million people are infected with HCV in the world (1).

$\mathrm{HCV}$ is the only member of the Hepacivirus genus and belongs to the Flaviviridae family. The positive polarity, enveloped RNA genome of 30-60 nm in diameter; encodes 10 proteins (5'-C-E1-E2-p7-NS2-NS3-NS4A-NS4B-NS5A-NS5B-3') (2). Six major genotypes and more than 80 subtypes have been identified since HCV was first diagnosed in the late 1980s. All genomes of the genotypes are different from one another at the rate of $\geq 30 \%$ at the nucleotide level while the sub-types under a certain genotype typically differ at that of $15 \%$ to $25 \%(3,4)$.

In recent years, a new variant called genotype 7 has been identified in patients in Canada and Belgium (4). HCV genotypes have a worldwide distribution and each genotype is classified into several subtypes with about $20 \%$ sequence variation (5).

The RNA dependent RNA polymerase enzyme is prone to make mistakes; it causes mutations in glycoprotein and other genomes. The high mutation rate and genomic heterogeneity of the viral genome has a decisive effect on the effectiveness of treatment (5).

The gold standard of genotyping is whole-genome sequencing analysis. This method is relatively expensive, and instead the protein coding regions such as 5'UTR, NS5B, and core region are used in the new-generation tests (6).

Epidemiologic studies have suggested that HCV genotypes are differently distributed between geographical areas, however, genotype 2 is less prevalent than genotype 1 throughout the world. Genotype 3a is more prevalent in South Asia, Australia, and Iran; genotype 4 in the Middle East, and Middle and North Africa; genotype 5a in South Africa; genotype 6a in Hong Kong and Vietnam; genotype 1b in South and East Europe; genotype 1a in North America and Europe $(7,8,9,10)$.

It has been reported in studies performed until today that genotype $1 \mathrm{~b}$ was the most prevalent genotype in Turkey $(11,12)$. Determining the prevalence of genotypes and their geographical variation is also important in terms of prognosis and treatment.

In our study, we aimed to determine the genotype distribution among hepatitis $\mathrm{C}$ patients followed up in our hospital and the potential variation of $\mathrm{HCV}$ transmission in our region within the years and ages.

\section{Materials and Methods}

We retrospectively analyzed medical records of 480 patients, who were diagnosed with acute hepatitis $C$ between January 2010 and May 2017 via anti-HCV (ELISA; Abbott Laboratories, the U.S.) and HCV RNA (real-time polymerase chain reaction (PCR); COBAS ${ }^{\circledR} \operatorname{TaqMan}^{\circledR} 48$ Analyzer, Roche Diagnostics, the U.S.]. In determining HCV genotype, a commercial kit (Ampliquality HCVTS; AB Analitica ${ }^{\circledR}$, Italy), which is based on Reverse Line Blot and called "line prob assay" (LiPA), was used in accordance with the manufacturer's recommendations. This test is based on the fact that the 5'UTR region of HCV RNA is amplified and hybridized with the oligonucleotide primers of the nucleic acids produced. In this test, all the six major HCV genotypes and certain HCV subtypes (1, 1a, 1b, 1a/1b, 2, 2a/2c, 2b, 3, 3a, 4, 4a, 5a, 6, 6a, or 6b) can be detected. The manufacturer identifies its detection sensitivity as $98.1 \%$ and its specificity as $100 \%$. We used bands formed in the way that the probes specific for various HCV genotypes are embedded around the nitrocellulose strips. The genotype distribution was reviewed by years. The first and only test results of the same patients were evaluated.

\section{Statistical Analysis}

For the data analysis, a software program, SAS University Edition 9.4, was utilized. In the data evaluation, analysis of variance (ANOVA) and a chi-square test were used; a $p$ value of less than 0.05 was considered statistically significant.

\section{Results}

Of the patients whose genotyping was made, 260 (54.2\%) were female and 220 (45.8\%) were male (Table 1). The average age of the patients was calculated as 59.2. It was found that 396 (82.6\%) of the 480 patients were with genotype $1 \mathrm{~b}, 17$ (3.5) genotype 1a, 15 (3.1\%) - genotype 3a, 14 (2.9\%) - genotype 1, 9 (1.9\%) - genotype 4, 8 (1.7\%) - genotype 2, 6 (1.3\%) - genotype 2b, 5 (1.0\%) - genotype 1a/1b, 4 (0.8\%) - genotype 2a/2c, $3(0.6 \%)$ - genotype $4 a, 1(0.2 \%)$ - genotype $3,1(0.2 \%)$ - genotype $5 a$ and $1(0.2 \%)$ patient was with genotype 6 (Table 2 ).

\section{Discussion}

The HCV genotypes determine the choice of treatment and the duration of the selected treatment. For HCV genotype 1, either the rate of response to interferon treatment is lower or the risk of progression of hepatocellular carcinoma is higher compared to other genotypes. Response to treatment in infected patients with HCV genotype 1 and 4 is lower than in those with genotype 2 and 3 and treatment duration is longer (5).

\begin{tabular}{|l|l|l|l|l|l|l|l|l|l|l|l|l|l|l|}
\hline \multicolumn{1}{|l|}{ Table 1. Distribution of genotypes by sex and mean age } \\
\hline Genotype & $\mathbf{1 a}$ & $\mathbf{1 b}$ & $\mathbf{1 a} / \mathbf{1 b}$ & $\mathbf{1}$ & $\mathbf{2 a} / \mathbf{2}$ & $\mathbf{2 b}$ & $\mathbf{2}$ & $\mathbf{3 a}$ & $\mathbf{3}$ & $\mathbf{4 a}$ & $\mathbf{4}$ & $\mathbf{5 a}$ & $\mathbf{6}$ & Total (\%) \\
\hline Number & 17 & 396 & 5 & 14 & 4 & 6 & 8 & 15 & 1 & 3 & 9 & 1 & 1 & $480(100)$ \\
\hline $\begin{array}{l}\text { Female } \\
\%\end{array}$ & 7 & 225 & 4 & 6 & 3 & 0 & 4 & 3 & 1 & 1 & 5 & 0 & 1 & $260(54.2)$ \\
\hline $\begin{array}{l}\text { Male } \\
\%\end{array}$ & 41.2 & 56.8 & 80.0 & 42.9 & 75.0 & 0 & 50 & 20.0 & 100.0 & 33.3 & 55.6 & 0 & 100.0 & \\
\hline Mean Age & 10 & 171 & 1 & 8 & 1 & 6 & 4 & 12 & 0 & 2 & 4 & 1 & 0 & $220(45.8)$ \\
\hline
\end{tabular}


Currently, there are many methods used for HCV genotyping. However, the gold standard of genotyping is the sequence analysis of the core, E1, NS5b and 5'-UTR regions and phylogenetic analysis made afterwards $(6,30,31)$.

However, the methods of sequence analysis require special equipment and experienced personnel. Therefore, it can be performed only in specific labs. We can count the other methods such as genotyping performed using PCR made by targeting the core or NS5b regions with genotypic primers; genotyping performed using restriction fragment length polymorphism (RFLP) made by clipping 5'UTR region with the restriction enzymes after PCR amplification; genotyping made by targeting 5'UTR, C, E1, NS3, or NS5b; genotyping by reverse hybridization after PCR with type-specific probes; and serotyping performed using C, E2 or NS4 region peptides $(30,31)$.

These methods used in performing HCV genotyping studies can determine major genotype groups but nonetheless, it is stated that their discriminatory power among the subtypes is not as effective as phylogenetic analysis (6).

In our study, we also used a commercial kit based on reverse line blot. In this test, based on the amplification of the $5^{\prime} U T R$ region of HCV RNA and hybridization of the resulting nucleic acids with oligonucleotide primers, dark colored bands formed by probes specific for different HCV genotypes attached to nitrocellulose strips were evaluated.

When the four main genotypes (Turkey posthoc) were statistically compared, the average ages of patients with genotype 1 and genotype $2(p=0.0003)$, genotype 1 and genotype 3 $(p=0.0001)$ and genotype 1 and genotype $4(p=0.0452)$ were found to be different from each other. The age distribution by genotypes is presented in Figure 1. When the four main genotypes were compared by gender using a chi-square test, there was a statistically significant difference among them $(p=0.0491)$. According to our study, the average age of patients with genotype 1 was higher than 60 years $(n=432)$ as in other countries. The highest reported HCV prevalence in the world was in Egypt, where the prevalence of infection increases steadily with age, and high rates of infection are observed among persons in all age groups (32).

In conclusion, it was found that genotype $1 \mathrm{~b}$, which has the highest prevalence in Turkey, is also the most prevalent genotype in our region by $82.6 \%$. The high incidence of genotype $1 \mathrm{~b}$ remained the same within the years, yet the ranking of other genotypes changed. In addition, the presence of genotype $5 a$ and genotype 6, which are rare genotypes in Turkey, has been reported.

In Turkey, there are many studies conducted at various times related to HCV genotyping. These studies have been done using many different methods such as reverse hybridization, PCR, RFLP, sequence analysis, pyrosequencing and LiPA. The results of these studies are presented in Table 3. In their study investigating the distribution of HCV genotypes in 7 regions of Turkey by evaluating 7002 patients with chronic HCV infection using LiPA method, Altindis et al. (13) found that $67.7 \%$ of patients had type $1 \mathrm{~b}$, 7.7\% had type 1, and 5.5\% patients had type 1a. In their study including $422 \mathrm{HCV}$ RNA-positive patients performed in Antalya, Sağlik et al. (15) determined that $63.3 \%$ of subjects had genotype $1 \mathrm{~b}, 14.7 \%$ had genotype $1 \mathrm{a}$ and $11.1 \%$ had genotype $3 \mathrm{a}$. In their study, Oztürk et al. (18), using the method of pyrosequencing of 639 samples, found genotype $1 \mathrm{~b}$ in $86.7 \%$ and genotype 2 in $9.3 \%$ of patients in Antakya and genotype $1 \mathrm{~b}$ in $55.2 \%$ and genotype 3 in $26 \%$ in Adana. Altuglu et al. (12) investigated serum samples collected from 535 patients with chronic HCV infection and reported that infection with subtype 1a and subtype $1 \mathrm{~b}$ was observed in $12.9 \%$ and $80.4 \%$ of patients, respectively. In studies performed in Turkey, the incidence of genotype $1 \mathrm{~b}$ has

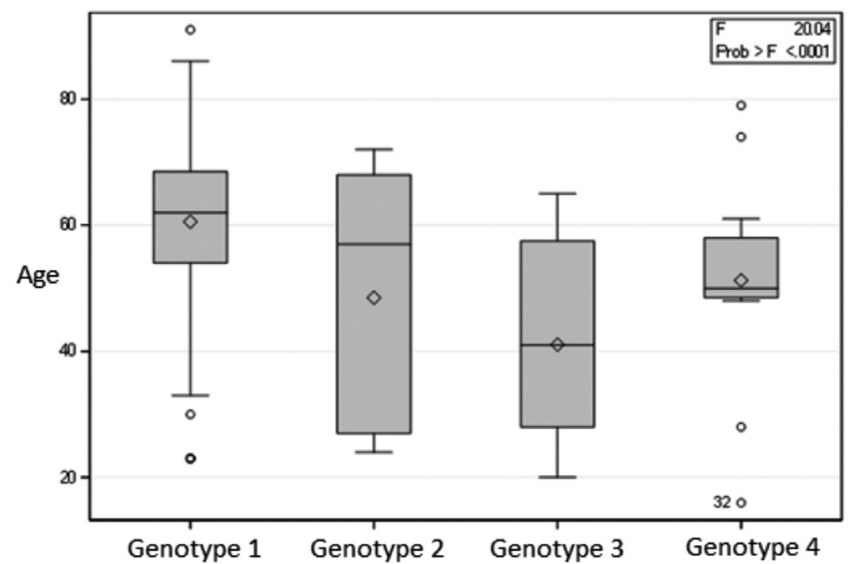

Figure 1. Age distribution by genotypes (ANOVA)

Table 2. Distribution of hepatitis $C$ virus genotypes by years

\begin{tabular}{|c|c|c|c|c|c|c|c|c|c|c|c|c|c|}
\hline \multirow[b]{2}{*}{ Year } & \multicolumn{4}{|c|}{ Genotype 1} & \multicolumn{3}{|c|}{ Genotype 2} & \multicolumn{2}{|c|}{ Genotype 3} & \multicolumn{2}{|c|}{ Genotype 4} & \multirow{2}{*}{$\begin{array}{l}\text { Genotype } 5 \\
5 a\end{array}$} & \multirow{2}{*}{$\begin{array}{l}\text { Genotype } 6 \\
6\end{array}$} \\
\hline & $1 a$ & $1 \mathrm{~b}$ & $1 a / 1 b$ & 1 & $2 a / 2 c$ & $2 b$ & 2 & $3 a$ & 3 & $4 a$ & 4 & & \\
\hline 2010 & 0 & 60 & 0 & 3 & 2 & 0 & 0 & 3 & 1 & 0 & 2 & 0 & 0 \\
\hline 2012 & 1 & 75 & 2 & 2 & 0 & 0 & 3 & 1 & 0 & 0 & 1 & 1 & 1 \\
\hline 2013 & 1 & 57 & 1 & 1 & 0 & 0 & 3 & 2 & 0 & 0 & 0 & 0 & 0 \\
\hline 2016 & 9 & 57 & 1 & 4 & 0 & 1 & 1 & 4 & 0 & 3 & 1 & 0 & 0 \\
\hline 2017 & 5 & 28 & 0 & 1 & 0 & 3 & 0 & 3 & 0 & 0 & 0 & 0 & 0 \\
\hline Total & 17 & 396 & 5 & 14 & 4 & 6 & 8 & 15 & 1 & 3 & 9 & 1 & 1 \\
\hline Percent (\%) & 3.5 & 82.6 & 1.0 & 2.9 & 0.8 & 1.3 & 1.7 & 3.1 & 0.2 & 0.6 & 1.9 & 0.2 & 0.2 \\
\hline
\end{tabular}




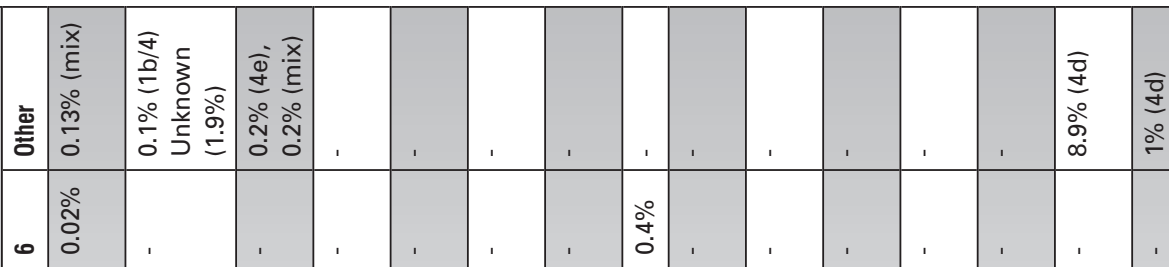

\begin{tabular}{|l|l|l}
\hline & $\stackrel{0}{\circ}$ & \\
\hline 0 & L & \\
\hline
\end{tabular}

$\stackrel{8}{\mathbb{8}}$

ڤ.ं.

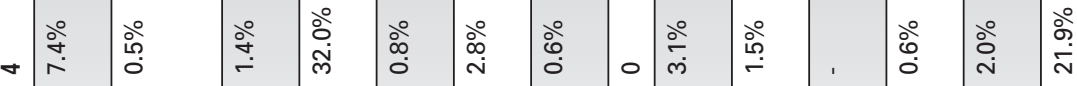

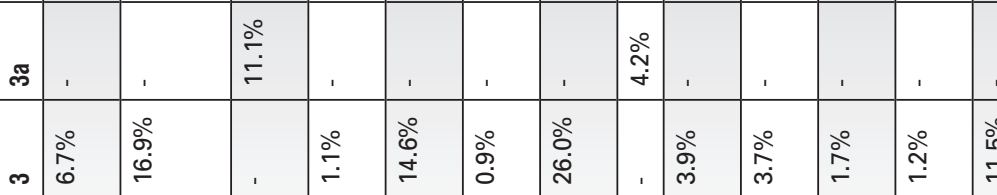

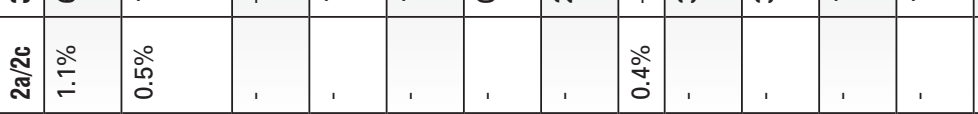

.

ะ

ڤ.

.

\begin{tabular}{|c|c|}
\hline & 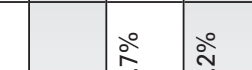 \\
\hline
\end{tabular}

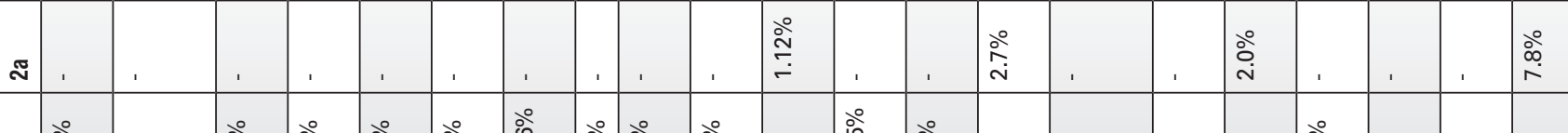

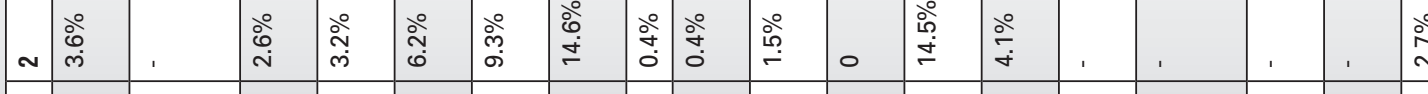

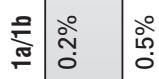

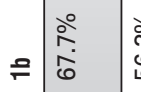

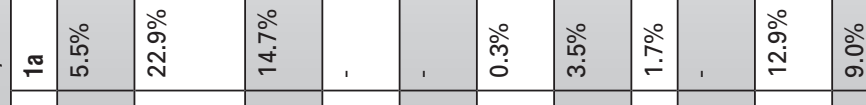

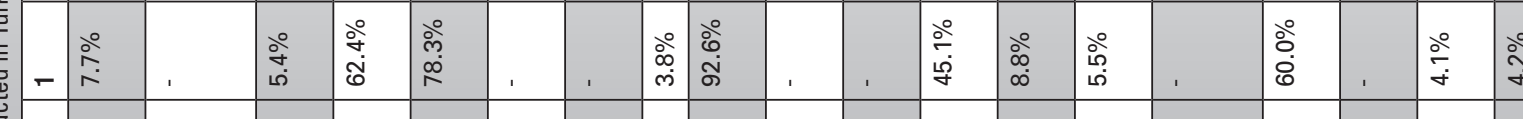

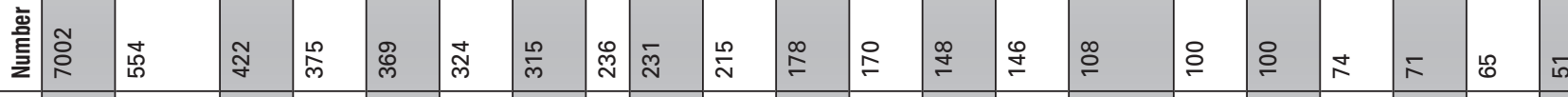

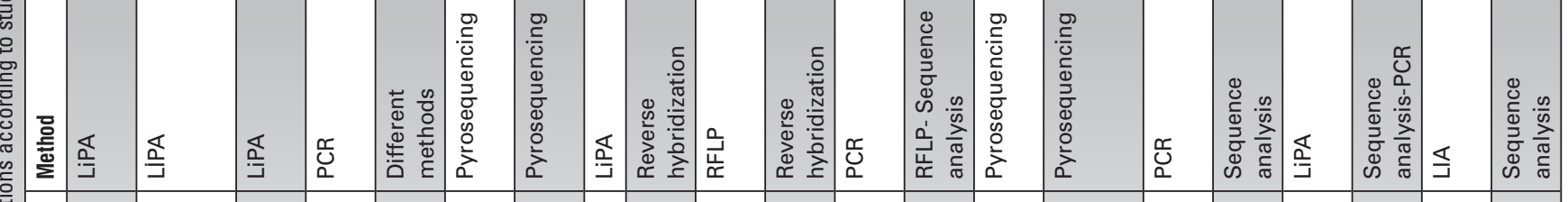

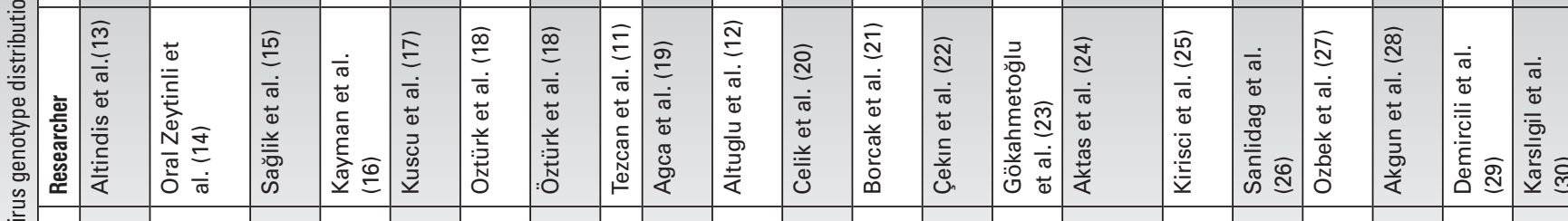

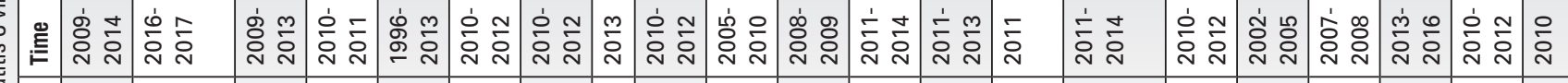

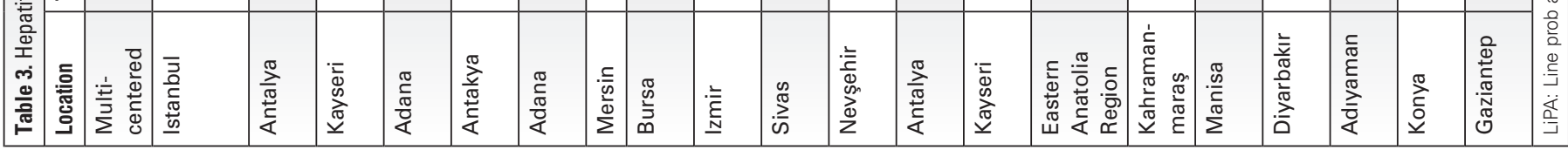


been reported in the range of $37-90.8 \%$ and the most commonly detected genotype was found to be genotype $1 \mathrm{~b}$. It is followed by genotype 1a, genotype 4, and genotype 3 respectively. Genotype $4 a$, genotype 5 and genotype 6 , which are rare genotypes, were detected at various rates.

\section{Conclusion}

In this study, we determined the distribution of HCV genotypes in our region, which is crucial for treatment regulations and in identifying prognosis and made a contribution to the epidemiologic data in the way of evaluating its trend within the last seven-year period.

\section{Ethics}

Ethics Committee Approval: There is no ethics committee approval because the study is retrospective.

Informed Consent: Since the study was retrospective, the patient's consent was not taken.

Peer-review: Externally peer-reviewed.

\section{Authorship Contributions}

Concept: U.T., Design: U.T., M.B., Data Collection or Processing: B.F., Analysis or Interpretation: M.Ö., Literature Search: B.S.G., Writing: U.T.

Conflict of Interest: There is no conflict of interest between authors.

Financial Disclosure: No financial support was received for the study.

\section{References}

1. Aman W, Mousa S, Shiha G, Mousa SA. Current status and future directions in the management of chronic hepatitis C. Virol J. 2012:9:57

2. Lindenbach $B D$, Rice $C M$. Unravelling hepatitis $C$ virus replication from genome to function. Nature. 2005;18;436:933-938.

3. Simmonds P, Bukh J, Combet C, Deleage G, Enomoto N, Feinstone S, Halfon P, Inchauspé G, Kuiken C, Maertens G, Mizokami M, Murphy DG, Okamoto H, Pawlotsky JM, Penin F, Sablon E, Shin-I T, Stuyver LJ, Thiel HJ, Viazov S, Weiner AJ, Widell A. Consensus proposals for a unified system of nomenclature of hepatitis C virus genotypes. Hepatology. 2005;42:962-973.

4. Smith DB, Bukh J, Kuiken C, Muerhoff AS, Rice CM, Stapelton JT, Simmonds P. Expanded classification of hepatitis $C$ virus into 7 genotypes and 67 subtypes: updated criteria and genotype assignment web resource. Hepatology. 2014;59:318-327.

5. Jimenez-Mendez R, Uribe-Salas F, López-Guillen P, Cisneros-Garza L, Castañeda-Hernandez G. Distribution of HCV genotypes and HCV RNA viral load in different regions of Mexico. Ann Hepatol. 2010:9:33-39.

6. Zein NN. Clinical significance of hepatitis $\mathrm{C}$ virus genotypes. Clin Microbiol Rev. 2000;13:223-235.

7. Ohno O, Mizokami M, Wu RR, Saleh MG, Ohba K, Orito E, Mukaide M, Williams R, Lau JY. New hepatitis C virus (HCV) genotyping system that allows for identification of HCV genotypes 1a, 1b, 2a, 2b, 3a, 3b, 4, 5a, and 6a. J Clin Microbiol. 1997; 35:201-207

8. McOmish F, Yap PL, Dow BC, Follett EA, Seed C, Keller AJ Cobain TJ, Krusius T, Kolho E, Naukkarinen R, et al. Geographical distribution of hepatitis $C$ virus genotypes in blood donors: an international collaborative survey. J Clin Microbiol. 1994;32:884892.
9. Simmonds $\mathrm{P}$, Holmes EC, Cha TA, Chan SW, McOmish F Irvine B, Beall E, Yap PL, Kolberg J, Urdea MS. Classification of hepatitis $C$ virus into six major genotypes and a series of subtypes by phylogenetic analysis of the NS-5 region. J Gen Virol. 1993;74:2391-2399.

10. Zarkesh-Esfahani SH, Kardi MT, Edalati M. Hepatitis C virus genotype frequency in Isfahan province of Iran: a descriptive cross-sectional study. Virol J. 2010;7:69.

11. Tezcan S, Ulger M, Aslan G, Yaraș S, Altıntas E, Sezgin O, Emekdaș G, Gürer Giray B, Sungur MA. Determination of Hepatitis C Virus Genotype Distribution in Mersin Province, Turkey. Mikrobiyol Bul. 2013;47:332-338

12. Altuglu I, Sertöz R, Aksoy A, Gürsel D, Tüzüner U, Günşar F. Possible transmission risks and genotype distribution of hepatitis C virus infection in Western Turkey. Turk J Gastroenterol. 2013;24:349-355

13. Altindis M, Dal T, Akyar I, Karatuna O, Gokahmetoglu S, Tezcan Ulger S, Kulah C, Uzun B, Sener AG, Ozdemir M, Aydogan S, Kuskucu MA, Midilli K, Otlu B, Celen MK, Buruk K, Guducuoglu $\mathrm{H}$. Six-year distribution pattern of hepatitis $\mathrm{C}$ virus in Turkey: a multicentre study. Biotechnology \& Biotechnological Equipment. 2016:30:335-340

14. Oral Zeytinli U, Muhterem Yucel F, Daldaban Dincer S, Yanilmaz O, Aksaray S, Ozdil K. Distribution of Hepatitis C Virus Genotypes in the Region of 'Istanbul Northern Anatolian Association of Public Hospitals'. Viral Hepat J. 2017;23:10-13.

15. Sağlik I, Mutlu D, Öngut G, Inan D, Öğünç D, Can Sarinoğlu R, Özhak Baysan B, Gültekin M, Colak D. Distribution of Hepatitis C Virus Genotypes among Patients with Chronic Hepatitis C Infection in Akdeniz University Hospital, Antalya, Turkey: A FiveYear Evaluation. Mikrobiyol Bul. 2014;48:429-437.

16. Kayman T, Karakukcu C, Karaman A, Gozutok F. Genotypic Distribution of Hepatitis C Virus Infection in Kayseri Region. Journal of Turkish Microbiological Society. 2012;42:21-26.

17. Kuscu F, Komur S, Inal AS, Cengaver Ulu A, Kurtaran B, Taşova $Y$, Unlu B, Mıdıklı D, Dogan Tombul Z, Yilmaz G, Suntun BM, Aksu HSZ. Changing Epidemiology of Chronic Hepatitis C in Adana. Viral Hepat J. 2014;20:15-18.

18. Oztürk AB, Doğan UB, Oztürk NA, Ozyazici G, Demir M, Akin MS, Böngöl AS. Hepatitis C virus genotypes in Adana and Antakya regions of Turkey. Turk J Med Sci. 2014;44:661-665.

19. Agca H, Kazak E, Mıstık R. Distribution of Hepatitis C Virus Genotypes in the South Marmara Region. J Clin Anal Med. 2015;6:190-192.

20. Celik C, Bakici MZ, Kaygusuz R, Ertürk R. The Searching of HCV Genotyping Distributions in the Region of Sivas. Viral Hepat J. 2010;16:106-110.

21. Borcak D, Cagır $U$, Yalciner A. Distribution of Hepatitis $C$ Virus Genotypes and Their Association with Serum Alanine Aminotransferases and Quantitative Serum HCV RNA Levels. Journal of Antimicrobial Chemotherapy. 2015;29:36-40.

22. Çekın Y, Gür N, Çekın AH, Altuğlu I, Yazan Sertöz R. Investigation of Hepatitis C Virus Genotype Distribution in Patients with Chronic Hepatitis C Infections in Antalya Training and Research Hospital, Turkey. Mikrobiyol Bul. 2014;48:484-490.

23. Gökahmetoğlu S, Atalay MA, Kılınç A. Determination of the Hepatitis C Virus Genotypes With. Pyrosequencing Method. Erciyes Med J. 2011;33:99-102.

24. Aktas O, Ozbek A, Aydın H, Ozkulekci MB. Distribution of HCV genotypes in patients of with chronic hepatitis $\mathrm{C}$ in the eastern anatolia region. Viral Hepat J. 2014;20:91-94.

25. Kirisci O, Calıskan A, Kocturk S, Erdogmus P, Gul M. The Relationship Between Distribution of HCV-RNA and ALT-AST Levels with Genotypes of Hepatitis C Virus Infected Patients. Viral Hepat J. 2013;19:67-70. 
26. Sanlidag T, Akçali S, Ozbakkaloglu B, Ertekin D, Akduman E. Distribution of hepatitis $C$ virus genotypes in Manisa region, Turkey. Mikrobiyol Bul. 2009;43:613-618.

27. Ozbek E, Ozekinci T, Mese S, Atmaca S. Hepatitis C virus genotypes are changing in the Southeast of Turkey. Biotechnol Biotechnol Equipment. 2009;23:1521-1523.

28. Akgun S, Tarhan G, Sayiner HS, Akgun I, Kok S. Determination of hepatitis $C$ virus genotype distribution in Adıyaman province. Ortadoğu Medical Journal. 2017;9:1-5.

29. Demircili ME, Ozdemir M, Feyzioglu B, Baysal B. The Efficiency of Hepatitis C Virus Core Antigen Test in the Diagnosis of Hepatitis C Infection. Viral Hepat J. 2016;22:18-22.
30. Karslıgil T, Savas E, Savas MC. Genotype distribution and 5'UTR nucleotide changes in hepatitis C virus. Balkan Med J. 2011;28:232-236.

31. Özen Karataylı SC, Bozdayı AM. Hepatitis C Virus Virology, Genotypes and Subgenotypes, Diagnosis. Türkiye Klinikleri J Gastroenterohepatol-Special Topics. 2010;3:70-76.

32. Medhat A, Shehata M, Magder LS, Mikhail N, Abdel-Baki L, Nafeh M, Abdel-Hamid M, Strickland GT, Fix AD. Hepatitis c in a community in Upper Egypt: risk factors for infection. Am J Trop Med Hyg. 2002;66:633-638. 